immedistely to a complete symmetrical theory of equations and algebraic functions, and greatly facilitating the solution of problems in applied mathematics. In fact the complex number, originally introduced tentatively and apologetically, now rules the whole realm of algebra Even yet, in spite of the infinite value of the thing, no satisfactory philosophical ground can be given for its introduction. Why should a science based on the principle of representing things by symbols require the introduction of a symbol which corresponds to no thing? We can no doubt find intellectual satisfaction in extending our algebraic and originally arithmetical processes to operations; but as we do so we are compelled to modify these very processes. Multiplication, for example, becomes what might be called polar, the value of a product depending on the order of the fuctors. By such imposed limitations we enrich the significance of a process and extend our methods.

We can but refer to the wide-reaching inquiry into the foundations of geometry, an inqu ry which has led to the conception of different kinds of space esch with its own consistent though to us unimaginable system of geometry. In the effort after a rigorous foundation of geometry, the mathematical mind has, in short, demonstrated the possibility of a kind of space whose properties it is incapable of imagining. The unthinkable and the impossible a re not convertible terms.

It is not possible to do more than touch upon the many phases of thought brought forward in Mr. Merz's pages. The difficulty in undertaking a history of acientific thought $i$, to decide what to lesve out. Certain broad issues are obvious to every one, such as the doctrine of energy and thermodynamics, the electromagnetic theory of light, the relation of ether and matter; but, in the discussion of these, secondary questions arise in the sifting of which judgment must be exercised. And in this respect Mr. Merz's history is worthy of our highest appreciation. As already pointed out we think the author has excelled himself in the presentation of the modern trends of mathematical thought. All men with any claims to intellectual power know a good deal about energy, electric waves, natural selection, and variation; but to the vast majority projective geometry and function theory are absolutely unknown, "number" suggests no deep philosophical discussion, and "space of four dimensions" is the one hyper-spacial phrase possessing any familiarity. Mr. Merz has done a great service by giving the intelligent reader who has had no training in the higher mathematics an opportunity of becoming familiar with the subtle searchings of some of our keenest inteilects.

C. G. Kмотт.

\title{
Brotogical Section.
}

In passing from the mechanical and physical views of nature to what may be roughly called 'biological' views, Merz emphasises 
the contrast between the abstract study of natural objects and phenomena - a study which introduces us to " the general relations or laws which govern everything that is or can be real,"-and "those sciences which study the actually existing forms as distinguished from the possible ones, the "here" and "there," the "where" and "how," of things and processes; which look upon real things not as exsmples of the general and universal, but as alone mssessed of that mysterious something which distinguishes the reas and actual from the possible and artificial'. This contrast between abstract and descriptive sciences raises the difficulty that in pursuing the latter, especially in their kinetic or physiological sepects, the investigator finds himself 'abstracting' just as the chemist and physicist did. Furthermore, the contrast leads the author to an extension of the concepts of the 'morphological,' the 'genetic ' and the 'vitalistic' views in a manner which may surprise the morphologist, the geneologist, and the physiologist as they actually exist. For it follows from the classification adopted that the morphologist, for instance, has crystals and minerals, why not also mountain-ranges and river-courses, within his province. To this he may object that what he took to do with was the study of the static relations of organisms, that, illogical as it may be, he does not find a long lost brother in the crystallographer or the mineralogist, and that the history of scientific thought in regard to the morphology of organisms must not be mixed up with the doubtless analogous study of the morphology of mineral forms or mountain-ranges, which involve quite different methods and disciplines. On the other hand, we may recall Huxley's confession that he was not really so much interested in the fact that the animals he so skilfully anatomised were once alive, as in the general problem of their structural 'make up'; he was, he said, an engineer in partibus infudelium. There is much to be said on both sides.

The author points out, that " one of the greatest changes which the present age has witnelsed has been the breaking down of the old landmarks and of the stereotyped divisions (between the sciences) which existed in the beginning and all through the first half of the (nineteenth) century"; and thus he feels a somewhat slack interest in the much-discussed problem of the classification of the sciences, as detailed, for instance, in Prof. Flint's recent erudite treatise.

"In the perpetual variety of change the morphological view tries to define those recurring forms or types which present themselves again and again, towards which all changes seem to revert; thus bringing some order into what would otherwise be disorder and confusion." "On the other side, the genetic view denls with the transit on from one form to another in the course of time; takes more interest in morement and in the process and function : and seeks for their probable laws and regulurities." This introluction to the norphological view of nature is admirably put, but the 
historical difficulty remsins that the logical distinctions are not, in point of fact, always applicable to the work of the masters who have mede our sciences of organisms what they are. Gegenbaur, for instance, perhaps the most illustrious comparative enetomist of the second half of the nineteenth century, was conspicuously a pure morphologist, and yet his whole work-though he seldom said a word about evolution, is pervaded by the genetic ides. A descriptive anstomist, of course he was, and we have not his equal now, but his whole morphology was evolutionist.

Of this difficulty Merz is well aware, and his chapter shows in an interesting way that many of the paths of investigation followed by the morphologists led them into new atmosphere and disclosed horizons much wider than they had dreamed of. Thus there were explorations in the graveyards of the buried past and excursions to far off lands; forms were studied in situ and living things visited in their habitats; the microscope revesled the innermost structure of organisms and an enormous creation of ininute beings invisible to the living lens by itself; the study of life-steges began to fascinate and morphology became morphogenesis; the grear architectural plsns on which living creatures are constructed began to stand out clesrly, the relatedness and apparent recurrence of definite types could not but arrest attention, and although 'the relationship was mostly looked upon as ideal, not resl,' there were isolated morpbologists before 1859 who were not ashamed to call themselves geneologists. Prof. Patrick Geddes, with his usual illuminating insight, has pointed out that the / rogress of morphology as such-from Buffon to Bütschli-is a story of more and more deeply penetrating analysis, from the external form and symmetry of the organism to the internal architecture of the organs, from the organs to the tissues which compose them, from tissues to their elementary units or cells, and from cells to the living matter itself. This summary gives a crispness to the historical retrospect, of which Merz might, we think, have taken more advantage but it must be remembered throughout that he is dealing not with the history of science but with the history of soientific thought, and that the mood or logio of the morphological analyst is the same whether he is studying an elephant or a Bacterium, a fossil or an embryo, a liver or a nuclear complexity of one of ite cells. In passing, $1 \theta$ doubt the risdom of spesking of the period 1800-1860 as dominantly morphological ; the geneological and physiological disciplines were often prominent during these decades, and morphology was never atronger than it is to-day.

There is $1 \%$ finer chapter in the book than the nintl which desls with ' the genetic view of nnture,'-the view which, eeks to give answer to the question, How have things come to be what they are? To Leibnitz with his 'Protogma' to Kant (influenced by the cosmical theories of Thomss Wright of Durham) with his 'Natural History of the Hearens,' to Laplace, forty years after 
Kant, with bis 'nebular hypothesis,' important initiative stimuli are due, but their attempts 'belong to the Romanoe of Soience'. More solid contributions to a resl genetic theory of the things of nature are to be found in the researches in palæontology and embryology which are associated with the names of Hutton ard Lyell, Wolff and von Baer. Thence, after a glanoe at Oken and his 'Natur-Philosophie,' the author reaches the pioneers of Evolu'.. unism, such as Lamarck and Treviranus, and finallv brings us to familiar ground in the work of Darwin and Wallace, Haeckel and Spencer. The story has been often told, but never better, for the author's unusually brosd outlook ensbles him to give due place to the many collateral influences, e.g., from physics and chemistry, whioh helped the doctrine of organic evolution to win conviction as a modal formula for the universal "Werden and Vergehen". In reference to this chapter we may call attention to the appreciation of the interesting and unique position which Karl Ernst von Baer occupies in the history of science and thought.

"It is from and thiough organisms, the-living things of nature, that we first learnt to look upon the whole of nature as having a history and a life. Imperceptibly we have been led to study life, the genesis of things, on the large scale and in the ubstract, and in so doing have lost sight of the life which goes on around and near us. Both the morphological and the genetic views of nature started with a biological interest, but have gradually lost sight of it." Buch considerations lead the author to "the vitalistic view of nature' which inquires into the actual processes of life, though still without any secure convictions as to what 'life' is. As was to be expected, much of his physiological chapter is concerned with the see-8aw of the two schools of so-called materialists and so-called vitalists. "After the age of Bichat, and largely through his influence,--l.e., through the cultivation of anatomical researches, -the pendulum swang in the direction of proving more and more the parallelism of organic and inorganic processes. It reacbed its maximum swing in that direction about the second third of the century. Since then it appears to have again returned in the opposite direction." It is this movement which the author follows with particular care, showing that "the stronghold in which the innermost secret of life is intrenched has been attacked from all sides by ali the processes and methods of the mechanical, physical, and chemical sciences, and how it has persistently refused to surrender". The chapter discusaes the intluence of Lavoisier, who applied the theory of combustion to living creatures: of Jjobig, who popularised the conceptions of "Stoffwechsel" (metabolism) and "Kreislauf des Iebens" (the circulation of matter), and was one of the first to look upon nuture as an econouy or a household; of Claude Bernard and Johannes Miller. of J.otze and Du Bois Raymoud, and of many others. Finally, through Virchow and others, we are led to the idea of the continuily of generations, a continuity of organisation. and of metabolic processes-and 
thence to Weismannigm and the all-embracing dynamic outlook on organic nature which this implies.

Pausing in his fascinating history, the author asks if we have come nearer an answer to the question, What is Life? "At one time, for a generation, which is passing away, we apparently had. But a closer scrutiny bas convinced most of us that we have not." We are far from being able to translate into mechanical categories the organisation, the metabolism, the adaptation, the selection, and similar formulw with which we work. "The spectre of a vital principle still lurks behind all our terms." And this leads the author naturally to his chapter on the psycho-physical view of nature, which has to do with the mental, inner, or self-conscious side of the higher forms of living matter, and discloses a new world within the old one, the miorocosm in the macrocosm. This will obviously lead on to the third volume, desling with philosophic thought in the ninetenth century. The twelfth chapter discuses the application of statistical methods to such phenomena as those of variation and heredity-a profonndly interesting and important subject, but we should not.have thought that it was worthy of boing dignified as 'the statistical view of nature'. It is only the applicetion of a special technical method, and promiseful as ite. results have been it does not appesr to us a new point of view.

There are, the author says, two grand and complementary conceptions which either underlie all soientific inquiry or result from it,- Order and Unity (in its noost impressive form, Individuality). He finds these two conceptions dominent in Biology as also in Physics. "The sciences of life have forced upon us more and more the conception not only of orderly arrangement but also of a unifying principle-that is, Individuality." The concept of Order is not merely static, it is progressive, and it leads the soientifio mind through the ides of continuity to that of Unity. In other words, the biological concepts of Order and of Unity combine in a concept of Evolution.

As we have given much attention to the history of Biology, since the time of Buffon, we may be permitted to record our appreciation of that part of Merz's volume which deals with the development of biological thinking. 'I he suthor's erudition is marvellous, yet amidst the tres he never loses sight of the wood. Unemberrassed by his wealth of materiel from original sources he advances serenely and sanely, disclosing step by step the magistral march of scientific progress. His general ideas are so akin to our own that we naturally find them hard to criticise, and his historical sketch is so much more comprehensive and consequent than that to which we attained that we cannot do more then express our grateful admiration. There are many students of science, philosophy, and history - who wish and need to know what the trend of biological science has been during the past century. They will find this and much more in the relevant chapters of this remarksble work, which it would be faint praise to call " Whewell up to date".

J. Arthur Thomson. 